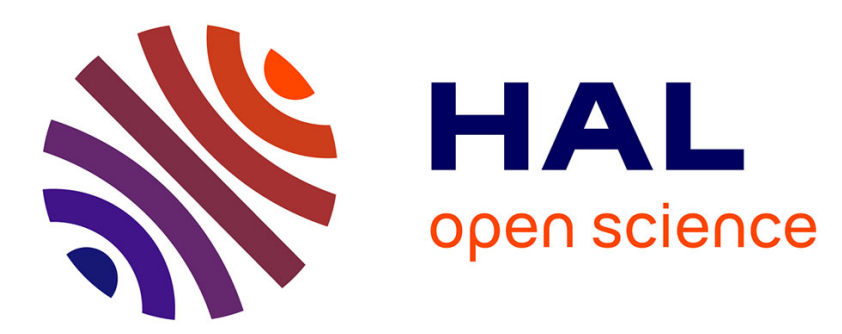

\title{
Women and the Economic History of the Ancient Greek World Still a challenge for gender studies
}

\author{
Violaine Sebillotte Cuchet
}

\section{To cite this version:}

Violaine Sebillotte Cuchet. Women and the Economic History of the Ancient Greek World Still a challenge for gender studies. 2015. halshs-01387030

\section{HAL Id: halshs-01387030 \\ https://shs.hal.science/halshs-01387030}

Preprint submitted on 25 Oct 2016

HAL is a multi-disciplinary open access archive for the deposit and dissemination of scientific research documents, whether they are published or not. The documents may come from teaching and research institutions in France or abroad, or from public or private research centers.
L'archive ouverte pluridisciplinaire HAL, est destinée au dépôt et à la diffusion de documents scientifiques de niveau recherche, publiés ou non, émanant des établissements d'enseignement et de recherche français ou étrangers, des laboratoires publics ou privés. 
Women and the Economic History of the Ancient Greek World

Still a challenge for gender studies

\author{
Violaine Sebillotte Cuchet \\ Université Paris 1 Panthéon-Sorbonne \\ UMR 8210 ANHIMA (Anthropologie et Histoire des Mondes Antiques)
}

Women and gender history, considered as an academic field, moved a lot since 2000, even in France. Therefore, every reader would expect to be enlightened on the methodological and theoretical positions assumed by the author of this paper. Working on the cultural context of ancient Greece and engaged in the specific scholarship background of French historiography (anthropological history renewed by feminism), my purpose is to develop the meaning of "women" for scholars, like me, who study individuals (male and female) in the gender era (part I). My second point is about the economic approach: working on the history of women in the field of economy is, on my point of view, a great challenge. Economic and gender scholarship really ever merge and this Conference is very interesting and innovative on this point (Part II). For this reason, joining gender and economic studies in Antiquity sounds very promising, even in Greek and classical studies. In engaging scholars in collecting various types of documents, textual and archeological ones, joining gender and economic studies also engages in throwing several and specific lights on the ancient society and its various ways of speaking of individuals, some documents underlining the distinction between male and female, some not (part III).

I. What benefit women studies gain from gender studies?

Women studies is a broad academic field. When gender studies started, in the sixties, it led to theoretical and politic divisions among American feminists. Let's speaks about the French version, many years later, of this great divide between women and gender studies. In 2002, a Conference was hold in Paris by a feminist academic association and the main point was to discuss the usefulness or not of gender in women's history (Fougeyrollas-Schwebel et al. 2003). The main arguments against gender were that $1 /$ gender was a new word (an English one) that French people wouldn't accept (French language can use « rapports sociaux de sexe », " sexe », « hommes et femmes », etc) 2/ gender was a way to avoid women and speak of social constructions without paying as much attention to real ancient people as one should 3/ gender was politically neutral and couldn't support a feminist cause. 
Gender's academic « success » was interpreted as proof of its lack of political weight.

It is quite funny to remind this argument though gender became that high controversial and political concept we know today. Since the Conference of 2002 in France to nowadays, gender has been largely adopted by International Organizations, scholars, even media. Nevertheless, even in 2015, no one can say that it turns to a politically neutral concept. In France, 2014 was a very bad year for gender studies: the French government, facing an "anti-genre" coalition, was finally obliged to move back and to erase gender from its vocabulary as Zancarini-Fournel pointed out (2014: 201-208). In this context, writing the history of women without gender could appear either "out of date" either politically marked. The point is not to discuss these connotations or short judgments but to throw light upon what is at stake when using gender in the field of history: what is the scientific gain, if any?

Gender means, as it is usual in English language, the social aspect of being a man or a woman. In the sixties and in a culturalistic perspective (Scott 1986: 1053-75), gender was a better word than women as gender meant the social interpretation of bodies whereas women referred to bodies for themselves. In contrast to French language, sex could not be used as it would have mostly meant sexuality ${ }^{1}$. In the international context, Gender was to be translated in many other languages, even in French where the word « genre » - even if French people often ignored it - was a good equivalent. From the $13^{\text {th }}$ century, "genre", translating the latin genus, has been used not only as a grammatical category but also as a sexual category (see Chevalier and Planté 2014: 13-31 and Offen 2006: 291-304). French feminists were unlikely to accept the word as it blurred bodies and sexual difference. But, at once, they did. On a way, the word allowed new questions. More important, it led to a decisive change in the scientific paradigm of Women history.

Gender was used as a category of analysis (upon to Joan Scott), that is to say, a scientific tool (recently and in a French context, see Scott 2012). Setting bodies and sex in the cultural sphere, considering gender as a category (as Greeks said the anthrôpon genos or the gunaikôn genos), led the way to a new question: what people do with sexual difference? Do they ignore it? Or does it make sense? If it does, why and how? Thus, sexual difference became a question by itself (Sebillotte Cuchet 2012: 573-603). Gender studies have also proved that the naturalization of sexual difference is an historical process. As

\footnotetext{
${ }^{1}$ In a important article about women agency, Lin Foxhall (1989: 24) makes the distinction very clear, using either gender, either sex: "In the course of even one lifetime roles, statuses, economic resources and even personnel change. Sex does not change, though gender roles may".
} 
Thomas Laqueur wrote in 1990, in the past, men and women could differ by what he called temperament or gender. In this organization of differences, various bodies were signs of various temperaments. From the modern medical point of view that has been developed since the middle of the $18^{\text {th }}$ century, female and male bodies were as different as apples and oranges are (Laqueur 1990; Steinberg 2008: 198). Laqueur's thesis has long been discussed and criticized (recently King 2013: 127 and 31-48). Today, gender studies are more sensitive to the different forms of discourses about sex and body, and scholars (as Holmes 2011) more sensitive to underline either gender fluidity (individuals could be perceived as feminine or masculine in different contexts) either gender fixity (one cannot be female and male, one can never change its sex - at least in Antiquity).

Therefore, the aim of gender studies, from my point of view, is not to describe women as a group of people sharing the same experience, by definition different from that of the group of men. What is at stake, by contrast, is to analyze the contexts, actions and functions that gave sense to sexual difference (in other words, the contexts that construct gender). Sexual difference, in this perspective, is a relative notion. What is different in being a priest or a priestess? A god or a goddess? A king or a queen? A salesman or a saleswoman? A female or a male prostitute? etc. Examining the difference is the necessary precondition before being able to say what women means, in each context. In other words, comparing women and men when engaged in the same function is a good method to understand how various societies, activities, documentary contexts, differentiate (or not) women from men (on this method, see Boehringer and Sebillotte Cuchet 2013). With the gender approach, the question of the place of women in history is definitely not the same as it was 40 years ago: we still use the category of women as our modern category but we actually are in search of what that category meant for the Ancient Greeks. Are we right to translate gunê by « woman » or does gunê meant wife? Or mother? Or is it just a name for a female body?

In analyzing the meaning given by the Ancient to the sexual difference, the benefits are not only for women studies but also for history as a whole. Actually, it is quite the rule that in Ancient societies the distinctions between individuals lay mostly on social status than on sexual status. Incidentally, we are not even certain of what "social status" and "individual" meant in Ancient Greece, as Boehringer pointed out in an anthropological perspective (Boehringer 2013: 5-18). As individualization is an historical process and ancient Greece is characterized by the agency of the divine, we should also asked the question whether a man acted by a female divinity, like Aphrodite, is entirely a "man", I mean someone with a psychological and personal identity and different from a "woman". Ancient gender characteristics should be put together in a more complex manner than in our modern use of the term gender. 
Thanks to gender studies, «women » are now in question. In the eighties, Black feminism underlined the historical and cultural gap between White women and Black women in the United States (Davies 1982). Actually, women as a homogeneous group do not exist. Therefore, what is of historical interest is to notice what makes women exist as a group. At this point I would insist how far gender radically transformed the questions usually asked about women and our ability to answer them. In this regard, Women studies are definitely not the same today as they were yesterday. Women studies gained gender studies, and we should not forget this and keep this point on mind: it helps to put women (back) in the question.

II. Economic and gender scholarship really ever merge

Working on women history in the field of economic is a great challenge as economic and gender scholarship really ever merge. Today, one main trend in economic studies is to propose and examine models of economic development, more or less ignoring the actors (for example, see Archibald, Davies, and Gabrielsen 2011). In The Cambridge Economic History of the Graeco-Roman World, edited by Ian Morris and Richard P. Saller in 2007, where room is left to sociological approaches, only one chapter out of 28 concerns women in ancient economy: This is the chapter devoted to « Household and gender » that includes women with children (15 pages out of 770 pages). It seems that women could not exist without children and outside the domestic sphere of the house. In the recent Companion to Women in the Ancient World, edited by Sharon L. James and Sheila Dillon, no more room is kept for the question of women in economics ${ }^{2}$. Although moved by a feminist claim, women's work within the house (oikos) and feminine patronage are, as usual, the only way to deal with women in economics.

Yet, it should be reminded that since the beginning of the eighties, feminist sociologists, even in France, have been leading a strand of scholarship that seriously contrasted the stereotypical picture of women at home they resumed by the phrase: "Seules les femmes sont inscrites dans une famille, seuls les hommes sont à leur place dans le monde du travail: des femmes inactives et des hommes sans famille" (Barrère-Maurisson 1984: 8). What was challenging in the beginning of the eighties of the

\footnotetext{
${ }^{2}$ In James and Dillon 2012, the main topics are historiography, medicine, law, and religion. Another trend is to discuss women's agency and women's representation (iconography, sculptures, portraitures). Only a few pages are devoted to women in economic (Pp. 325-326 laying upon the papyri documentation and Pp. 478-490 in Emily A. Hemelrijk's paper about the occidental part of the Roman Empire).
} 
last century is still challenging at the beginning of the $\mathrm{XXI}^{\text {st }}$ century.

The fact is that this very traditional representation of men (at work) and women (at home) is still at the background of most scholars, as I tried to show with the two examples quoted above. Still now, it seems natural to assume that, in Antiquity, women were consumers (obviously only consumers) and men producers (obviously never consumers) ${ }^{3}$.

Three points present valuable alternative to escape from this stereotypical opposition:

1/ Taking into account the bias of the vocabulary. Pieter Herfst, in a classical and still valuable book published in 1922, listed the feminine Ancient Greek words used for female trades (Herfst 1979; Savalli 1983: 81-89). Maria Cecilia D'Ercole, in a recent paper, stressed that only 1 out of 5 of the Ancient Greek merchants' terms Pieter Herfst listed, did exist on a feminine form (D’Ercole 2013: 55). What does that mean? That women were less involved in commercial activities, as D'Ercole suggests? I think one should be very cautious with such an interpretation. One the one hand, we must keep in mind that the large invisibility of female workers is often due, even in modern languages, to the male oriented vocabulary (masculine forms are used for generic forms, what we call masculine epicenes) ${ }^{4}$. The question is a methodological one that influenced the whole comprehensiveness of societies. A few years ago, Cynthia Patterson noticed that politai - usually translated as "citizens" and, in French,

\footnotetext{
${ }^{3}$ Let see, for exemple, Julien Zurbach's comment to Works and Days 376-380 ( Puisses-tu n'avoir qu'un fils pour nourrir le bien paternel - ainsi la richesse croît dans les maisons - et mourir vieux en laissant ton fils à ta place. Mais, à plusieurs enfants, Zeus peut aisément aussi donner une immense fortune : plusieurs font plus d'ouvrage, plus grand est le produit ») : « Hésiode parle de mariage à plusieurs reprises et aussi du nombre de fils. Ce qui est important dans ce passage n'est sans doute pas tant le nombre de fils que le fait même que ce soient des fils, plutôt que des filles ou des petits-enfants en bas âge. Cela signifie qu'ils peuvent travailler avec leur père, c'est-à-dire que le grand nombre de fils installe à l'intérieur de la famille une proportion favorable entre ceux qui travaillent la terre et ceux qui ne la travaillent pas. On comprend mieux dès lors ce jugement sur le nombre de fils, qui est assez important pour entrer en conflit dans ce passage avec la grande méfiance d'Hésiode envers les héritages par division, qui incitent au contraire à réduire leur nombre. On touche ici à la question de l'équilibre entre besoins et travail, qui est fonction de la relation entre nombre de producteurs et nombre de consommateurs au sein d'une cellule domestique qui apparaît clairement comme le principal, sinon le seul, horizon économique d'Hésiode » (Zurbach $2009: 16$ ).

${ }^{4}$ Still rare are the papers assuming the question of gender and of language. It is notworthy to note that, in $1898\left(1^{\text {st }}\right.$ ed.), the Recueil des Inscriptions Juridiques Grecques, did mention this discrepancy between lexical and grammatical gender and individuals involved in the Epicteta's will (circa 200 BC): "L'objet du testament est la création d'une corporation ou communauté perpétuelle, comprenant tous les parents mâles de la testatrice, présents et à venir; les présents sont dénommés, au nombre de vingt-cinq, en tête le gendre et le frère adoptif d'Epictéta. Cependant quoique la communauté soit expressément qualifiée de corporation masculine ( $\alpha v \delta \rho \varepsilon i ̃ \varsigma$, , II, 29 et suiv.), la testatrice, par une disposition supplémentaire (§9), décide qu'on y admettra également: $1^{\circ}$ les femmes des premiers membres et leurs filles tant qu'elles seront en puissance de leurs pères; $2^{\circ}$ les descendantes (sans doute seulement par les mâles) des membres originaires, tant qu'elles remplissent la même condition; $3^{\circ}$ les épiclères avec leurs maris et leurs enfants; $4^{\circ}$ à titre exceptionnel, huit femmes (avec leurs maris et leurs enfants), dont l'une est la fille épiclère de la testatrice, deux les soeurs de son gendre, trois les filles ou soeurs de membres du kowvóv." (Dareste, Haussoullier, and Reinach 1965: 106-107).
} 
"citoyens" (only male) - was used in epic and tragedy to describe the inhabitants of the polis, pouring out water form the well or watching at the war behind the walls of Troy (Patterson 1987: 49-67). From this activity and the context, one could affirm that those politai were mostly female citizens. In economic context, let's think of the word talasiourgos that means the wool's worker but can be used for both male and female worker. In the inscriptions of the phialai exeleutherikai, attesting about 375 slaves' enfranchisements in Athens at the end of the fourth century, the word qualifies women, not men (Tod 1997: 113-124, Wrenhaven 2009: 367-386). Inscriptions mentioned the price paid for manumissions and sometimes names and occupation of the persona manumitted. On the 63 women mentioned with their occupation, 51 (or $81 \%$ percent) are designated as talasiourgoi.

2/ Keeping in mind that the male distribution of civic (public) functions does not mean that women were out of the economy. We can guess that very often, only the man had the function, but the female members of the family were also at work. As C. Chandezon noticed in a recent article and about Xenophon's Oeconomic: « the responsibility for bookkeeping in the estate falls not on the overseer but on the mistress of the house, Ischomachos' wife, who plays the role of the tamias, the treasurer. She has to receive the harvests, calculate and organize the expenditures, assess the amount of reserves to be made and "make sure she spends not in one month the expenses planned for one year." (Xen. Oec. 7.36, Chandezon 2011: 108). Female workers were almost not visible because of texts oriented by androcentric's organization and shaped by masculine forms of language. In this case, deduction could help a lot. Let's take an example: even if textile production is not well known due to the lack of archeological data, we know Greek people considered this work as a women's role, and it was probably so (iconography, archeology, epigraphy, textual tradition repeatedly stressed what can be understood as a common assumption). Various elements otherwise allowed C. Chandezon to affirm that textile production was of great importance in Ionia: a special race of sheep was used to produce a highly famous wool from the $\mathrm{VI}^{\text {th }}$ century to the Hellenistic period (Chandezon 2003: 200-201). Working at home or in collective fabrics, women must have played a central role in the production of this regional wealth, as it is hardly improbable that there were only male workers.

3/ Taking into account all the data concerning women at work or engaged in economic transactions and not only the textual documentation transmitted by the manuscripts' tradition. Works and Days, the Hesiodic poem written to advice Perses from getting far away from dikê, the good behavior, set up the figure of the peasant living in the VII ${ }^{\text {th }}$ century. The social environment is full of naughty people and the weather not that good. The poor peasant trying to escape the fate of poverty and slavery, shall 
become this one who is moved by the good eris, the good struggle, not the bad one. The good eris engages him to work in his fields in order to make his home prosperous (Works and Days 17-23). The vivid description is rooted in the present of the poet and his audience: the Iron Race must struggle and work for life. This situation is explained by the poet as a consequence of Prometheus's metis: the grain has been hold by Zeus under the earth, evil and sickness have spread over, hard labor has became necessary to live, sexual union imposed to the new Race, the Iron Race, made each one a mortal. Beside its misogynistic and even misanthropic tone, the poem - didactic in producing an ethic of good life - does not tell us anything about women in economy except incidentally. One can read that the ideal is to keep in winter the young girl at home, with her mother, spinning the wool. We could infer that working the wool is a women's ideal task ${ }^{5}$. The main purpose of the landowner is to keep its property free and transmit it to his children. Thus, the social reference of the narrative is the one of the oikos in its patrimonial aspect: coming from the father and transmitted to son(s). In this picture, the wife couldn't be anything else than a sexual partner whom function is to giving birth to the potential heirs. In this narrative, and because of the narrative choice of $W D$, nothing else is expected from her.

It is true that this oppositional ideal between men and women is repeated, even in a different form, in one of the most important written evidence for Classical period, Xenophon's Oeconomic: husband and wife are set as complementary managers, each one organizing its own sphere, the indoors and the outdoors, on his own. This oppositional organization is based on an interpretation of the bodies: the male one is as tough as the female is soft (Oec. VII, 18, 22-28). This didactic treaty is correctly commentated as an ideal for a valuable citizen life: getting married and taking care of the estate to transmit it to heirs. Once more, the narrative choice engaged the oppositional and complementary depiction of the spouses.

Archaeological data confirmed these narrative codes: funerary steles and vases displayed images of women in domestic activities or management of domestic staff. The stereotypical opposition of the spindle and its stalk for spinning wool and the hoplite panoply is very well known even as a literary topos $^{6}$. This norm is highly political: it applied to the world of landowners, a world of female and male citizens in Classical Athens. But, even in the world of citizens, these political norms can not be considered as reflecting any social or economic reality. François Lissarrague demonstrated in 1990

\footnotetext{
${ }^{5}$ Pandora, the first wife (gunê), is described skilled in weaving (v.64), an ambivalent attribute (v. 373, 375). Nevertheless,

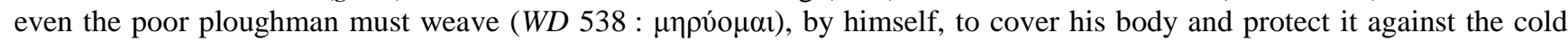
winter (see West 1978: 294). So, if women are mainly engaged in textile tasks, it is unlikely that only women were doing textile work : sewing, weaving, spinning and carding. A recent bibliography's survey in Brøns 2014: 85-89.

${ }^{6}$ Herodotus IV 162 ; IX 109 ; Aristophanes, Lysistrata 530-538 ; Polyen, Strategemata VIII, 53.
} 
how far images of women at the loom were far from describing labor. Vases often show women in brilliant dress, with garlands, jewelry and sometime heroic names such as Clytemnestra, Iphigenia, Cassandra. For the people looking at the images, could it be anything else that an idealistic world where work is done without sweat (Lissarrague 1991: 229-231)?

I would like to underline, at this point, how far the economic functional division between men and women, producers and consumers, is deriving from textual tradition and from this very specific point of view of the household and its claim to transmission through male generation. To go further on, I need to present the archaeological data that lead to a very contrasting opinion about women at work. In other words, the archeological date help to understand how diverse were the situations of women (and men) and how far, women could act, in social life, as economic partner.

III. Women's place in Ancient Greek Economy: stakeholders, individuals' agency and documentary norms.

Textual tradition, often repetitive, tells us a lot about civic attitudes, social and political concerns, ethical behaviors, but not about everyday life. By contrast, the archaeological data is diverse, heterogeneous and usually not conform to the civic norm we find in texts. Historians are, therefore, always confronted with the question of the general, or, on the reverse, the question of the unique. What is at stake is the representativeness of each document and the representativeness of each woman? As we still don't have, and probably never, the exhaustive database that could allow us to make statistics, we are actually trying to examine each assertion and generalization in order to find out both the purpose of the author/producer of the document and/or the documentary regulations that imposes particular formula or mises en scène. In other words, the variety of acts displayed by archeological data had also to conform to norms. Some vases, for example, could repeat textual norms when those vases are intended to promote an idealized vision of men or women. But they could, by contrast, carry on different meanings particularly when they intend to make people laugh (Lissarrague 2013). A minima archeological data displayed various performances of life.

Women's involvement in economic transactions: Thespies and Tenos

Ten years ago, Isabelle Pernin, analyzed various stelai found in Thespies (Beotia), dated from the second half of the III ${ }^{\text {rd }}$ century BCE (Pernin 2004, Colin 1897). Those inscriptions are lease contracts ( $\mu$ í $\theta \omega \sigma \iota \varsigma)$ on behalf of the city, landowner of public estates. The most complete is inscribed on a 
limestone stele (height about $0,77 \mathrm{~cm}$ x length $0,50 \mathrm{~cm}$ ), with an irregular and unclear script presently in the museum of Thespies. Its context of discovery is unclear, coming from a ppoúpiov located above the modern village of Erimocastro. On this stele, 25 plots ( $\gamma v \dot{\alpha \imath}$ ) are rented. Previous locators have priority to renew their previous agreement except if they had misbehaved. Nine plots changed of renters. The 25 plots concerned not 25 persons but only 16 persons (as one single individual can rent more than one plot) including two male children (Thumias and Rhodios) and three women. The women are always involved as new renters, like the two "boys" and also a man, named Poleas (plot 22). All the new renters invoked a parentage with the previous one: the children, Thumias and Rhodios are the paides of Pouthodotos; Poleas is the brother of Pherekleios, Zopyra the sister of Dionysios, Dinophila the daughter of Ismeinodoros. Phrounicha, the last woman mentioned, declares being the closest relative to Wimmpidas whom she succeeded in taking the location of two plots.

In those transactions women, less involved than men ( 3 out of 16), acted on their own. The formula is the same for man and women: name of the previous renter (if any), name of the renter, parentage with

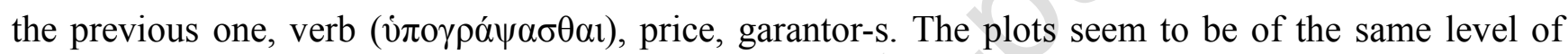
fortune (we don't have all the information) whereas they are rented by men or women. The women

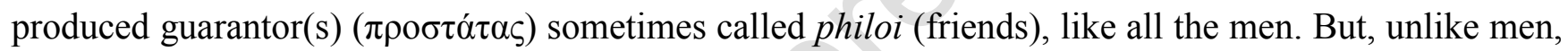
women need to present also a witness that Isabelle Pernin called an assistant (the Greeks used the word $\pi \alpha \rho \varepsilon \tilde{\alpha} \alpha v$ that indicates that the presence along with the woman. Zôpira, daughter of Dionysos, rented a plot, previously rented by her brother Dionysodôros. She presented two witnesses, Poleas son of d'Archias and Saôsias son of Sôsipolis, and three friends (philoi) came along with her ( $\pi \alpha \rho \varepsilon \tilde{\alpha} \alpha v$

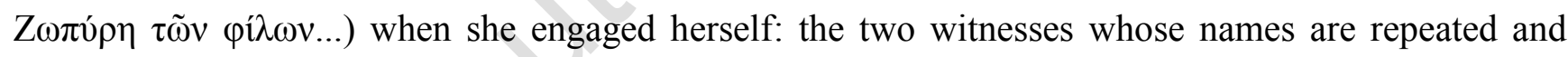
Dionysios son of Dionysios. Dinophila, daughter of Ismeinodôros presented two witnesses and produced her husband Archias (without patronymic) as an 'assistant'. The husband produced is

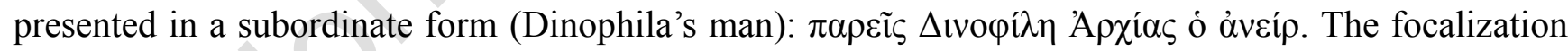
is upon the one, whether male or female, who acts as a renter.

Another piece of evidence for women involvement in economic transactions is the stele of sales from Tenos. It is the most important document attesting sale contracts and none document of this nature have been founded in Attica. The stele noticed 47 agreements listed in a chronological way and covering a period of one year and half. The stele might have been erected in a public space and the dating is from the archontat of Ameinolas at the end of the fourth century BCE or beginning of the 
third ${ }^{7}$.

Roland Etienne who analyzed the stele noticed that women were involved in 30 agreements out of 47 , and in 5 out of the 8 most important (on a financial point). We can notice that the formula is the same for men and women: name of the buyer, patronymic, name of the tribe; name of the seller, patronymic and name of his tribe. From the end of the nineteen's century, the stele has been commented from a juridical point of view. Different types of sales have been noticed in these agreements (new sales, results and developments of previous transactions, parts of familial economic strategies. See Etienne 1990: 52-67 and Game 2008: 105). The question of the economic agency of the women quoted in the inscription has never been precisely considered except by Claude Vial and Anne-Marie Vérilhac who underlined it (Vial and Vérilhac 1998: 125-207). Otherwise the debate is over-simplifyed by considerations about the discussed «freedom» of «Teniotes Women» compared to "Athenian women » (Etienne 1985: 61-70).

What are the main conclusions of the scholarship?

1/ As in the Thespian agreements, when a woman is involved in Tenos, she acts like a man. The verb is exactly the same as for a man ( $\dot{\pi} \pi \rho i \alpha \tau)$. The plot might be described with mention of the neighbors men or women (Petale: §35). Sometimes, the land is noticed to have been possession of a previous owner who could have been a woman, thus Timothea $(\$ 28)$ and Archestrate (\$30). Thus, it is clear that some women were landowners ${ }^{8}$. Those women could participate in properties exchanges, as men do and are, thereby, involved in financial transactions (usually mortgage, other attestations in Vial and Vérilhac 1998: 179-195).

2/ Some women could possess lands that were not part of a dowry but personal estates. Thus Pheido, daughter of Chabyssios, owned a plot given by her maternal grand father, and participate to a joint ownership (joint-stock company?) that also belongs to her mother Iphikrite and her brother Chairelas II. Iphikrite, herself, daughter without brother, possess properties coming from her own father, Chairelas I. The women's properties do not come only from dowries $(\S 33, \S 36, \S 38, \S 39, \S 40, \S 41$; Vial and Vérilhac 1998: 156 and 167).

3/ Sometimes, previous ownership is mentioned, and among these landowners, a few are women: Timothea ( $(28)$ and Archistrate ( $(30)$. Etienne considers that when previous landowners are

\footnotetext{
${ }^{7}$ CIG II, 2338 ; IG XII 5, 872 ; IJG I : 64-87 ; Etienne 1990 : 51-84 ; Game 2008 : 173-190 (text and translation). Image : British Museum 1818,0110.4. I use the numerotation of the agreements followed, since IJG, by Etienne 1990 and Game 2008, from $\S 1$ to $\S 47$, with the new edition of the Greek text, by Hiller von Gaetringen (IG XII 5, 872).

${ }^{8}$ Foxhall 1989 : 22-44. Vial and Vérilhac 1998 : 152 and 187-91 for other examples and the conclusion : «La majorité des historiens et des juristes ont sous-estimé la place tenue dans les dots par les biens immobiliers. Les exemples dont nous disposons sont nombreux et viennent de régions diverses. »
} 
mentioned that means that the real property is still theirs and that the transaction is purely a loan, not a sale (Etienne 1990: 54-55). Without discussing the conclusion of the argument, we notice that the presence of women mentioned as previous landowners of the plot "in sale" clearly indicate that women were considered as "real" landowners. The same could be deduced from the mention of female neighbors: thus Petale $(\S 35)$.

4/ Actually, in some occasions, the consent of a woman is asked for. This makes sense if we consider, as it is usual, that the land the man wants to "sell" is part of the mortgage on the wife's dowry (for the "general mortgage" on the husband properties, see Vial and Vérilhac 1998: 195-97 and 202-203). Thus, Thespieus son of Thespieus, Aristonas son of Arsistolochos and the community of Theoxeniastes bought to Artumachos son of Aristarchos some estates that have been previously their own property

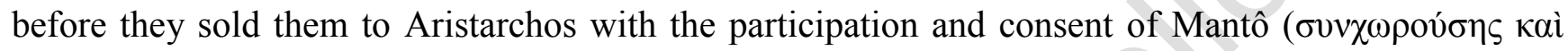

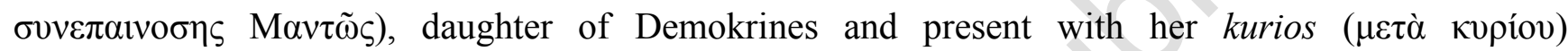
Artumachos himself ( $(45)$. In other words, the kurios is here interpreted as the husband. But, in another agreement, we can read that two men give their consent, and in quite the same way as Mantô does: "Kalliphon son of Kteton, Heraclides, baught to Phokos son of Phokion, Thruesios, the house that was previously owned by Kteton, his father, the neighbors being Simias and Kallikrates, for 1700

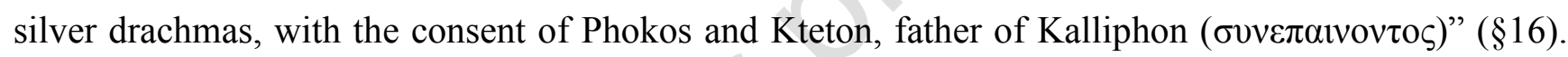
The consent is given by the father of the buyer and by the seller, who previously bought the house to the father of the buyer. The sale looks like a loan mortgaged on a house. No woman is involved in the transaction. Nevertheless, the same formula of the consent applied here for men.

The interpretation of the sale as a prasis epi lusei has often be taken as an argument to say that it was only to find money or protected their dowries that women were involved in financial agreements. But, the appreciation of the distinction between a sale and a loan is very difficult to make - the prasis epi lusei is only known, by the name, in Athens (Finley 1952, Game 2008: 168) - and often argued by previous (personals) ideas about what might be the right place of women in ancient society ${ }^{10}$. Instead

\footnotetext{
${ }^{9}$ Jean Game majes the point very clearly and underlines the specificity (in our documentation) of Tenos: Game $2008: 167$.

${ }^{10}$ Etienne 1985: 64 : «Sous les termes d'achat et de vente se cache une simple circulation d'hypothèques sous la forme de prasis epi lusei (vente à pacte de rachat), bien connues par la documentation de l'Attique . Dans ce mouvement des créances qui passent de main en main un seul point reste obscur. «L'ancien propriétaire », Eurykratès, conserve-t-il des droits de propriété, ou le bien a-t-il été acquis par Amphylis en pleine propriété ? Il est difficile de trancher, mais dans ce type de contrats je penserais volontiers que l'expression «biens qui appartenaient auparavant à .. » ne sert pas de référence supplémentaire pour désigner l'objet du contrat, venant s'ajouter à la mention des voisins, mais doit établir ou rappeler les droits réels de la personne nommée. J'entends donc qu'Eutykratès reste propriétaire - et peut-être même occupant - d'une moitié de ferme sur laquelle une hypothèque a circulé, passant deux fois dans les mains d'Amphylis ». I do underline. The author alludes to Tenos $§ 12$.
} 
of reasoning only in terms of dowries and mortgages ${ }^{11}$, that implies putting women in a different economy (as passive partners), I suggest that it would be useful to reason in term of individuals (even rooted in collective networks such as the household, kinship and political associations) because, as I noticed at the beginning of this paper, feminist historiography - even in the rare studies devoted to female agency in economic - continuously understood gender as a cognitive system based on two complementary and oppositional poles.

\section{Gender and individuals'agency}

One very influential paper on the subject of women's agency in economic might have been the one of Lin Foxhall who argued against the traditional view of passive women largely spread in scholarship since David Schaps' book of 1979. In 1989, Lin Foxhall described her method as a gender one: Llyod's description of polarity and analogy in Greek culture (Llyod 1966) pushed her into affirming that "in ancient Greek culture, broadly speaking, it can be argued that pairs of complementary oppositions are a fundamental aspect of cognition, intruding into every corner of social interaction from $\mu \varepsilon \dot{v}$ and $\delta \varepsilon \dot{\varepsilon}$ to men and women" (Foxhall 1989: 23). She added that "the most usual contexts for gender are provided by the poles of another complementary opposition: the private world of the household and the public world of the community" (ibidem). The major point she made was to make scholars fully aware of the implicit of texts (Athenian documentation from the $\mathrm{IV}^{\text {th }}$ century), of the solidarity of the household (including males and females) and of the distinction between legal and social descriptions ${ }^{12}$. Social relations could not be confused with legal formulations ${ }^{13}$. Nevertheless, her use of gender (metaphor of social roles that could change within the household depending of age, place in the family, accident of

\footnotetext{
${ }^{11}$ It is true that the beginning of the inscription does not help the understanding : «About lands, houses's sales and constitution of dowries », IJG I : 64. 1.1.

${ }^{12}$ For this last point, Foxhall took distance from the juridical approach of D. Schaps who concludes in 1979 on the existence, in Greece, of «the status of women » (Foxhall 1989: 98). The point is clearly made in Foxhall $2013: 44$ and 158: "And yet, it is clear that although gender may present itself most clearly as a dichotomy of male and female, the lived reality was far more complex, not least because of its intersections with other socio-cultural and political factors (age, class, status, wealth, etc.)", with a reference to what sociologists call insectionality.

${ }^{13}$ See on this point the anthropological analysis of the society of Karpathos in the XX ${ }^{\text {th }}$ century «Dans cette sociéte, marquée par ailleurs par le tabou des relations sexuelles avant le mariage ainsi que par une très forte séparation entre les sexes, les enfants de chaque sexe sont en effet condamnés, notamment par suite des exigences parentales, à se préoccuper sans cesse et depuis le plus jeune âge du sort, des intérêts et des désirs des enfants de l'autres sexe avec qui ils sont engagés dans un courant d'échanges particulièrement intensifs: constitution des dots sororales avec ce que cela peut impliquer de sacrifice, accompagnement au bal, aide dans la recherche d'un mari et protection d'un côté, avec comme contrepartie de l'autre, reconnaissance, admiration, respect, dons symboliques (louanges) et services domestiques divers »(Vernier 1985: 22-23).
} 
life...) and sex (being a female or a male) was not so easy to understand. Actually, gender, presented as "the most vigorous expression of meaning available to ancient Greek culture" overlaps, in her analysis (Foxhall 1989: 23), the male/female opposition (unify in the ideal context of household).

Less than ten years after Lin Foxhall's paper, Christiane Sourvinou-Inwood published, in 1995, another influential article that stresses, once more, the organization of Ancient Greek society, divided between a private and a public sphere, a male and a female sphere. As Sourvinou-Inwood demonstrated: "it is not the case that in Classical Athens women were excluded from the public sphere; they played an active role in public life in religion, as priestesses and other cult personnel as well as worshippers; that is, they played an active role in central part of polis activity, in which women were complementary and equal to men" (Sourvinou-Inwood 1995: 112). Besides, and contra Foxhall, she underlined how subordinated were women in the oikos.

None of these studies, produced in the eighties or the nineties, used gender as I do when I consider the concept as a scientific tool to put in the question the division between men and women in Antiquity (Scott 1986; Schmitt Pantel 2009). It is useful to take this new question at the fore and to make the step done by gender studies from a description of complementary oppositions (male/female; men/women) to the question of the meaning and the relevance of such an opposition.

The main point of the previous discussion concerns the ability of women to act by themselves, otherwise, the conditions of their ownership, or, in other words, their right to dispose of property ${ }^{14}$. It is in terms of degree of freedom or subordination that R. Etienne introduced its article about women, land property and money in Tenos published in 1985: Would Cycladic women have been more emancipated than "their Athenian sisters" (Etienne 1985: 61-70)? Upon to R. Etienne, the direct involvement of women in the sales contracts of Tenos should not be interpreted as a sign of more freedom for them. The main argument against their agency was the presence, along with them, of their kurios ${ }^{15}$.

Roland Etienne was true in pointing the fact that women in Tenos were engaged in transactions with the constant guardianship of their husbands (or brother or someone else of their family). Actually, the only difference between men and women involved in transactions in the Tenos' stele is that women are

\footnotetext{
${ }^{14}$ Foxhall 1989: 24-27. The discussion goes back to Schaps 1979, himself giving the previous steps of the scholarship in his preface (p. v-vi) and discussing - very briefly - the notion of property (Schaps 1979: 2).

${ }^{15}$ «L'intervention des femmes dans les contrats ne doit pas pourtant laisser croire qu'elles jouissaient d'une plus grande « liberté » qu'à Athènes. La présence d'un kyrios est toujours requise pour que leur action soit juridiquement valable. Les formules sont donc exactement les mêmes que lorsqu'il s'agit de mineurs : en ce sens, les principes du droit à Ténos sont bien les mêmes qu'à Athènes. L'émancipation de la femme, qui progresse à l'époque hellénistique en dehors du cadre de la cité, ne passe certainement pas par Ténos. » (Etienne 1985: 62).
} 
identified not only by the grammatical form of their name but also by the presence of a kurios, introduced with the coordination " $\alpha \alpha$ '” or " $\mu \varepsilon \tau \alpha$ " or the participle "ท๊ $\nu$ ". Anyway, we could not infer the function of the kurios from its nomination and we can be sure that, even done "with" a kurios, or with the attendance of men - as it is the case in Thespia - the act is the woman's one. We never get the formula that the kurios bought, sold or consented on behalf of a woman.

Lin Foxhall thus suggested to read the economic transactions at the intersection of both household and public spheres. Because the transaction concerning wealth of the household needed to "operate in the legal/political sphere, it had to be represented by a household member capable of acting in this sphere: an adult male, normally the head of household. The consequence is that the holder of this key position also becomes highly visible in the documents" (Foxhall 1989: 43). Two different agencies are at stake, the one in the household (male or female) and the one in the legal/political sphere (male).

Nevertheless, the male legal sphere does not overlap the public one. The women acting in these agreements were highly visible for their contemporaries, and this visibility is yet a step passed in the political/public sphere ${ }^{16}$.

At Tenos, the stela was erected in a public place and the engraving was done under the control of magistrates, the astynomoi, equally naming women and men. It is, I presume, a strong argument to say that women were part of economic exchanges, whether those exchanges were land or money. Women could control wealth without shame neither for them neither for their male relatives. The public visibility of these women gave to them social recognition. In Olynthus, an inscription recording the transaction between Xenon and Euboulides named two guarantors ( $\beta \varepsilon \beta \alpha \omega \tau \alpha \alpha)$, Pytheeas, Pythion's son, and Philaina, Heron's daughter. Philaina does not need a kurios to act like a guarantor (Game 2008: 62). This inscription, from $350 \mathrm{BCE}$, has been found in situ, in the ruins of a house near the north-east angle of the Agora. Located by the entrance, the stone was visible by everyone coming in the house. Everyone could read the name of Philaina and she must have benefit of the social esteem of all (Game 2008: 171-172).

It is right that citizens women, in well known Greek cities, needed a tutor, the kurios, for certain public acts they were engaged in ${ }^{17}$. But, it is also important to notice that recent works moved towards putting in perspective the influence of the kurieia, stressing its formal nature. For example, comparing Greek women and Egyptian women involved in loans contracts preserved on Egyptian papyri from the III ${ }^{\text {nd }}$

\footnotetext{
${ }^{16}$ For a recent discussion about these categories, see now Azoulay 2014: 605-26.

${ }^{17}$ Not all acts if we think of the well known exemple of the loan made, by 223 BCE, by Nikareta from Thespia to the city of Orchomenos : Migeotte 1999 : 247-57. Her husband, present as a kurios, is mentionned in only one occasion, when Nikareta made the Orchomenians aknowledge their debt.
} 
to the $\mathrm{II}^{\mathrm{nd}}$ century BCE, Damien Agut and Anne-Emmanuelle Veïsse pointed out that the kurioi mentioned in those contracts had no repercussion on the decisions (Agut and Veïsse 2014: 415-23). Indeed, Egyptian and Greek women act in the same way, whether they have a kurios or not. The kurios mention, always present in agreements made by Greek women, seems to be used as a formal clause and linked to only very specific legal acts, in other words, to documentary traditions (Veïsse 2011: 125-37).

To sum up, the legal sphere were the kurios intervenes is not homogeneous, neither in the Greek world neither in all period of Greek history, and probably neither inside the same city. The legal sphere is not synonymous to "public sphere" as visibility of women is very well attested in various aspects of the public life, such as the religious practices (Sourvinou-Inwood 1995: 114-18). The economic transactions involving women interfere both with legal practices (written agreements), political (magistrates record the contract) and social practices (households interactions): women could not be said confined in another world that would be the household and the domestic sphere. Actually, the women mentioned in the sale or loan contracts are rich women, with high social status. Is it fair to consider them as "women", apart from "men", or do we have to compare - and we did it with very simple words - rich men and women, opposed to poor men and women?

On this point, the question meets on this point with the lack of documents. We know by Attic orators Athenian women citizens who became that poor that they needed to work: some were nannies, others sellers, others grape pickers and others farm workers (Scheidel 1995: 207-10; 1996: 1-10, D’Ercole 2013: 64-65). Plato is even more explicit when he said, in Laws 805 d-e, that in Thracia and in many other places, women were harvesting, an unusual occupation for women in Athens, Plato added. Roger Brock, in an important paper published in 1994 suggested that textual documents, coming from the highly normative ideology of the complementarity of the inside and the outside, downplayed the fact (Brock 1994: 336-346). Actually, even in the very didactic hesiodic Works and Days, one can read: «First build a house (oikos) and get an ox for the plow (boun te arotêra), and a woman (gunaika) for a price (ktêtên) - no formal wedding (gametên) - to follow your oxen (bousin hepoito) » (WD: 405-406). A woman bought for a price meant that nobody can pretend any kind of property over her body and children (unlike the spouse in formal weeding), except the one who bought her. She did not get any dowry to manifest her own property and wealth (deriving from her family's) against her husband. The high vulnerability of poor women was a topos in Athenian comedy: one poor Megarian citizen tried to sell his daughters, wife and mother, because of hunger (Acharnians, 729-775 and 811-817). Women, in this case, were not far away from slavery (Jameson 1977/8: 137-38, Foxhall 2013: 96). The glorious Eurykleia, wet-nurse of Odysseus, is this kind of woman, both free and slave, doing all the work a 
female slave do, including sexual work (Scheid 2015) ${ }^{18}$.

To conclude, one can say that there were, in Ancient Greek societies, as many situations for women as for men. The gap between archaeological data and textual tradition is huge. The bias of textual tradition is not only androcentric (I mean because of the language that use masculine forms for generic purposes) but also ideological: texts focused on "ho boulomenos", the homopoliticus' type. And, even if archeological data exist and increase in publications and interest, the work is actually in its infancy to understand how far the fact of being born a girl influenced one's adult role in the economy and society. I try to demonstrate that to answer that question, it is important not to think that women were all considered in the same way, as female, and that their story is another story, apart from political, economic, social characterizations. The legal dispositions that make the differences between male and female, only concerned men and women of citizen status and social importance. In this group, women - always less represented than men - did have economic and financial capacities, depending on the composition of their native household and their involvement in strategies of acquisition. The Male and female, public and private, ancient and modern for historians, is less to evaluate a global subordination than to understand that conditions make the subordination effective.

Bibliography

Agut-Labordère, Damien, and Veïsse, Anne-Emmanuelle. 2014. Grecques et Egyptiennes dans les contrats de prêt aux IIIe et IIe siècles av. J.-C. Pp. 415-23 in Le myrte \& la rose. Mélanges offerts à Françoise Dunand par ses élèves, collègues et amis, 2, ed. Gaëlle Tallet and Christiane Zivie-Coche. Montpellier: CENiM 9.

Archibald, Zobia H., Davies, John K., and Gabrielsen, Vincent. 2011. The Economies of Hellenistic Societies. Third to First Century BC. Oxford: Oxford University Press.

Azoulay, Vincent. 2014. Repenser le politique en Grèce ancienne. Annales HSS 69/3: 605-26.

Barrère-Maurisson, Marie-Agnès (ed.). 1984. Le Sexe du travail. Grenoble : Presses universitaires de

\footnotetext{
${ }^{18}$ Scheid 2015, forthcoming. The question of prostitution as sexual work should be considered as part of economic transactions. Schaps excluded this activity from his study because he focuses on the «ordinary free Greek woman » (Schaps $1979: 2$ ). The point is that we do not know what makes a free Greek woman that « ordinary ».
} 
Grenoble.

Boehringer, Sandra. 2013. Vingt ans de réflexion. Mètis et le genre (1992-2012). Pp. 5-18 in Des femmes en action. L'individu et la fonction en Grèce antique ed. S. Boehringer and V. Sebillotte Cuchet. Mètis hors série $n^{\circ} 1$. Paris-Athènes : Éditions de 1'EHESS-Daedalus.

Boehringer, Sandra, and Sebillotte Cuchet, Violaine. 2013. Des femmes en action. L'individu et la fonction en Grèce antique. Mètis hors série $\mathrm{n}^{\circ} 1$. Paris-Athènes : Éditions de 1'EHESS-Daedalus.

Brock, Roger. 1994. The labour of Women in classical Athens. Classical Quaterly 44 (ii): 336-46.

Brøns, Cecilie. 2014. Gods and Garments. Textiles in Greek Sanctuaries in the 7th-1st Centuries BC. $\mathrm{PhD}$ diss. University of Copenhagen: SAXO Institute.

Chandezon, Christophe. 2003. Les campagnes de l'Ouest de l'Asie Mineure à l'époque hellénistique. Pp. 193-217 in L'orient méditerranéen, colloque de la SOPHAU 2003, ed. Francis Prost. Rennes : Presses Universitaires de Rennes.

Chandezon, Christophe. 2011. Some aspects of large estate management. Pp. 97-121 in The Economies of Hellenistic Societies ed. Zobia Archibald, John K. Davies, and Vincent Gabrielsen. Oxford: Oxford University Press

Chevalier, Yannick, and Planté, Christine. 2014. Ce que le genre doit à la grammaire. Pp. 13-31 in Qu'est-ce que le genre? ed. Laurie Laufer and Florence Rochefort. Paris:

Colin, G. 1897. Inscriptions de Thespies. BCH 21: 551-571.

Dareste, Rodolphe, Haussoullier, Bernard, and Reinach, Théodore. 1965. Recueil des Inscriptions Juridiques Grecques. II. $2^{\text {nd }}$ ed. Roma: L'Erma di Bretschneider.

Davies, Angela. 1982. Women, Race and Class. London: The Women's Press Ltd.

D’Ercole, Maria Cecilia. 2013. Marchands et marchandes dans la société grecque classique. Pp. 53-71 in Des femmes en action. L'individu et la fonction en Grèce antique, Mètis H.S., ed. Sandra Boehringer and Violaine Sebillotte Cuchet. Athènes, Paris: Daedalus, Éditions de l'EHESS.

Etienne, Roland. 1985. Les femmes, la terre et l'argent à Ténos à l'époque hellénistique. Pp. 61-70 in La femme dans le monde méditerranéen 1. Lyon: Maison de l'Orient.

Etienne, Roland. 1990. Ténos II, Ténos et les Cyclades du milieu du IVe siècle av. J.-C. au milieu du IIe siècle après J.-C. Athènes, Paris: ÉFA, De Boccard.

Finley, Moses I. 1952. Studies in land and credit in ancient Athens, 500-200 b. c.: the HorosInscriptions. New York: Columbia University Press.

Fougeyrollas-Schwebel, Dominique, Planté, Christine, Riot-Sarcey, Michèle, and Zaidman Claude. 2003. Le Genre comme catégorie d'analyse. Sociologie, histoire, littérature. Paris: L'Harmattan.

Foxhall, Lin. 1989. Household, Gender and Property in Classical Athens. The Classical Quaterly 39/1: 
$22-44$.

Foxhall, Lin. 2013. Studying Gender in Classical Antiquity. Cambridge: Cambridge University Press.

Game, Jean. 2008. Actes de vente dans le monde grec. Témoignages épigraphiques des ventes immobilières. Lyon: Maison de l'Orient Méditerranéen.

Herfst, Pieter. 1979. Le travail de la femme dans la Grèce ancienne. $2^{\text {nd }}$ ed. Utrecht: Arno Press.

Holmes, Brooke. 2011. Gender: Antiquity and Its Legacy (Ancients \& Moderns). Oxford: I. B. Tauris, Oxford University Press.

James, Sharon L., and Dillon, Sheila. 2012. A Companion to Women in the Ancient World. Malden, MA, Oxford, Chichester: Wiley-Blackwell.

Jameson, Michael H. 1977/78. Agriculture and Slavery in Classical Athens. The Classical Journal 73/2: $122-45$.

King, Helen. 2013. The One-Sex Body on Trial: Using the Classical and Early Modern Evidence. Ashgate: Farnham.

Laqueur, Thomas. 1990. Making Sex. Body and Gender from the Greeks to Freud. Cambridge, London: Harvard University Press.

Lissarrague, François. 1991. Femmes au figuré. Pp. 159-251 in L'Histoire des femmes en Occident, ed. Georges Duby et Michelle Perrot. Vol. 1. L'Antiquité, ed. Pauline Schmitt Pantel. Paris: Plon.

Lissarrague, François. 2013. La cité des satyres. Une anthropologie ludique (Athènes, VIe-Ve siècle avant J.-C.). Paris: Éditions de l'EHESS.

Lloyd, Geoffrey E. R. 1966. Polarity and Analogy. Two Types of Argumentation in Early Greek Thought. Cambridge: Cambridge University Press.

Migeotte, Léopold. 1999. Affairisme féminin à haute période hellénistique. Saitabi. Revista de la Facultat de geografia i Historia 49: 247-57.

Offen, Karen. 2006. Le gender est-il une invention américaine ? Clio FGH 24: 291-304.

Patterson, Cynthia. 1987. Hai Attikai : The other Athenians. Rescuing Creusa: new methodological approaches in antiquity, Helios 13 (2): 49-67.

Pernin, Isabelle. 2004. Les baux de Thespies (Béotie). Pp. 221-32 in Les hommes et la terre dans la Méditerranée gréco-romaine. Pallas 64/2004. Toulouse: Presses Universitaires du Mirail.

Savalli, Ivana. 1983. La donna nella società della Grecia antica. Bologna: Pàtron.

Scheid, Evelyne. 2015. Eurykleia, une vie, un nom. Pallas 99: forthcoming.

Scheidel, Walter. 1995 and 1996. The most Silent Women of Greece and Rome : Rural Labour and Women's Life in the Ancient World (I) and (II). Greece \& Rome $2^{\text {nd }}$ ser. 42/2 and 43/1 : 202-17 and 110. 
Schmitt Pantel, Pauline. 2009. Aithra et Pandora. Femmes, genre et cité dans la Grèce antique. Paris: L'Harmattan.

Scott, Joan W. 1986. Gender: A Useful Category of Analysis. The American Historical Review 91/5: 1053-75.

Scott, Joan W. 2012. De l'utilité du genre. Paris: Fayard.

Sebillotte Cuchet, Violaine. 2012. Régimes de genre et Antiquité grecque classique. Annales HSS 67/3: 573-603.

Shaps, David. 1979. Economic Rights of Women in Ancient Greece. New York: Columbia University Press.

Sourvinou-Inwood, Christiane. 1995. Male and female, public and private, ancient and modern. Pp. 111-20 in Pandora ed. Ellen D. Reeder. Baltimore: Trustees of the Walters Art Gallery in association with Princeton University Press.

Steinberg, Sylvie. 2008. Sexe et genre au XVIIIe siècle. Quelques remarques sur l'hypothèse d'une fabrique du sexe. Pp. 197-212 in Ce que le Genre fait aux personnes, ed. Irène Théry, and Pascale Bonnemère. Paris: Éditions de l'EHESS.

Todd, Stephen C. 1995. Status and Gender in Athenian Public Records. Pp. 113-24 in Symposion 1995. Vorträge zur griechischen und hellenistischen Rechtsgeschichte, ed. Gerhard Thür and Julie Vélissaropoulos. Köln: Böhlau Verlag.

Veïsse, Anne-Emmanuelle. 2011. Grecques et Égyptiennes en Égypte au temps des Ptolémées. Clio. Femmes, Genre, Histoire 33: 125-37.

Vernier, Bernard. 1985. Stratégies matrimoniales et choix d'objet incestueux (Dot, diplôme, liberté sexuelle, prénom). Actes de la recherche en sciences sociales 57-58: 3-27.

Vial, Claude, and Vérilhac, Anne-Marie. 1998. Le mariage grec. Du VIe siècle av. J.-C. à l'époque d'Auguste. BCH suppl. 32. Athènes, Paris: EFA, De Boccard.

West, Martin L. 1978. Hesiod. Works \& Days. Oxford: Clarendon Press.

Wrenhaven, Kelly N. 2009. The identity of the "whool-workers" in the Attic manumissions. Hesperia 78: $367-86$.

Zancarini-Fournel, Michelle. 2014. Les mouvements socio-politiques en France contre la "théorie du genre". Fondements, effets et ripostes. Genesis XIII/1: 201-208.

Zurbach, Julien. 2009. Paysanneries de la Grèce archaïque. Histoire et sociétés rurales 31: 9-44. 